\title{
GROWTH EFFECTS OF THE EXCHANGE-RATE REGIME AND THE CAPITAL-ACCOUNT OPENNESS IN A CRISIS-PRONE WORLD MARKET: A NUANCED VIEW
}

\author{
Assaf Razin \\ Yona Rubinstein \\ Working Paper 10555 \\ http://www.nber.org/papers/w10555
NATIONAL BUREAU OF ECONOMIC RESEARCH 1050 Massachusetts Avenue
Cambridge, MA 02138
June 2004

We acknowledge comments from Alex Cukierman, Allan Drazen and Alejandro Izquierdo. We are in debt to Gian Maria Milesi Ferretti for providing us data. The views expressed herein are those of the author(s) and not necessarily those of the National Bureau of Economic Research.

(C2004 by Assaf Razin and Yona Rubinstein. All rights reserved. Short sections of text, not to exceed two paragraphs, may be quoted without explicit permission provided that full credit, including $\subseteq$ notice, is given to the source. 
Growth Effects of the Exchange-Rate Regime and the Capital-Account Openness in A CrisisProne World Market: A Nuanced View Assaf Razin and Yona Rubinstein NBER Working Paper No. 10555

June 2004

JEL No. F0, F4

\section{$\underline{\text { ABSTRACT }}$}

It has been a remarkably difficult empirical task to identify clear-cut real effects of exchange-rate regimes on the open economy. Similarly, no definitive view emerges as to the aggregate effects of capital account liberalizations. The main hypothesis of the paper is that a direct and an indirect effect of balance-of-payments policies, geared toward exchange rate regimes and capital account openness, exert a confounding overall influence on output growth, in the presence of sudden-stop crises. A direct channel works through the trade and financial sectors, akin to the optimal currency area arguments. An indirect channel works through the probability of a sudden-stop crisis. The empirical analysis disentagles these conflicting effects and demonstrates that: (i) the balance-ofpayments policies significantly affect the probability of crises, and the crisis probability, in turn, negatively affects output growth; (ii) controlling for the crisis probability in the growth equation, the direct effect of balance-of-payments policies is large. Domestic price crises (high inflation above a 20 percent threshold) affect growth only indirectly; through their positive effecton the probability of sudden-stop crises.

Assaf Razin

Eitan Berglas School of Economics

Tel Aviv University

Tel Aviv 69978

ISRAEL

and NBER

razin@post.tau.ac.il

Yona Rubinstein

Tel Aviv University

yonar@post.tau.ac.il 


\section{Introduction}

Every major international economic crisis of the past 15 years (save Brazil in 2002) has been rooted in rigid exchange rate regimes. ${ }^{1}$ Indeed, there has been a long-standing view that an emerging economy under a peg, with government budget imbalances, trade deficits, and the presence of free-market policies that facilitate the outflow of capital, is likely to become vulnerable to sudden stops of capital inflows; hence, to balance of payments crises. This is also the familiar logic of every fundamentals-driven currency crises models in the literature.

A more nuanced view of growth effects of a peg recognizes that by fixing their currencies to international moneys (the Dollar or the Euro), fiscally-disciplined emerging economies, that are rapidly accumulating exchange reserves through export growth, are able to maintain a high saving ratio, provide certainty to business, and profit margins to investors, based on a low and stable country specific rate of interest. Under this macroeconomic environment, an emerging economy could retain the confidence of the international investors, and the peg leads to a good economic performance in the long run: output growth is high, and inflation is low. In other words, switching from a float to a peg presents the economy with a trade-off: on the one hand, the risk of a currency crisis is aggravated; but, on the other hand, if a currency crisis is avoided, the economy may actually perform better than what it would have been under a float. ${ }^{2}$

\footnotetext{
${ }^{1}$ Stanley Fischer (2001) observes that: "Each of the major international capital market-related crises since 1994-Mexico, in 1994, Thailand, Indonesia and Korea in 1997, Russia and Brazil in 1998, and Argentina and Turkey in 2000-has in some way involved a fixed or pegged exchange rate regime. At the same time, countries that did not have pegged rates-among them South Africa, Israel in 1998, Mexico in 1998, and Turkey in 1998-avoided crises of the type that afflicted emerging market countries with pegged rates."

Among the ecent papers on the vulnerability of fixed exchange rate regimes for developing countries, see Calvo (2000), Calvo, Reinhart and Vegh (1995), Chang and Velasco (2000), Ghosh, Gulde and Wolf (2000), Obstfeld and Rogoff (1995) and Williamson (2000).

${ }^{2}$ Trade-offs concerning the choice of exchange rate regimes are faced by policy makers when developing countries struggled with bouts of high inflation. A switch from float to peg typically serves as an anchor of the stabilization package. Examples are Israel (in 1985), and Argentina in (1991), underpinned the anti-
} 
It has been conspicuously difficult, however, to identify clear-cut empirical real effect of exchange-rate regimes on the real side of the open economy, for two main reasons. The endogeneity of policy tools with respect to macroeconomic performance, and the confounding effect of policy. Most studies focus on the first issue, typically by instrumenting the policy variables, but ignored the later issue. The purpose of this paper is to tackle both issues, namely, to delineate the "good" and the "bad" effects, arising from a policy switch. Specifically, we introduce the effect of the policy on the probability of sudden stops of capital inflows, and incorporates this projected balance-of-payments crisis probability into the growth equation.

The Asian crisis of 1997-1998 could be viewed as a watershed in the international economics thinking concerning exchange rate regimes, the international contagion of macroeconomic instability from one country to another, and the deregulation of international capital flows. One of the lessons is that, in the presence of weak financial and fiscal institutions, balance-of-payments crises often follow up capital account liberalizations.

Accordingly, the paper also pursues an analysis of capital-account openness policies, in parallel to the analysis of the policy switch between a peg and a float. Specifically, we analyze the two possibly conflicting channels through which a switch from a regime of capital controls to a regime of capital-account liberalization affect growth, in the presence of crisis-prone financial market. The de-regulation of international capital flows, working through cross-country interest parities, constrain domestic growth by enhancing the inflation policy package by an exchange rate targeting. Argentina adopted a hard peg (a currency board), with a comprehensive capital market liberalization package, while Israel adopted a soft peg (crawling peg), with only a phased out process towards capital market liberalization. As might have been expected, given the world economy recession after Israel's stabilization and the world economy boom that followed the Argentine's inflation stabilization, Argentina grew faster than Israel in the immediate aftermath of the float-peg policy switch. However, eventually, Argentina underwent a catastrophic currency and liquidity crisis. As Paul Krugman puts it: "Argentina, once a showpiece for the new world order, quickly became a byword for economic catastrophe" (The New York Times, January 6, 2004). In contrast, Israel has avoided a major crisis. Ten years after the float-peg policy switch, the accumulated growth in Argentina was negative, while the trend growth in Israel has been significant. See Fischer and Orsmond (2002). 
probability of financial crises. ${ }^{3}$

We also propose a re-examination of discrete high inflation crises. Typically, growth falls sharply during discrete high inflation crises. By introducing a probability of domestic (high inflation) crises, along with the probability of external (balance-of-payments) crisis that depends on the exchange rate system, we are able to further discern the non-linear effect of the exchange rate system, or capital account openness, on growth.

The organization of the paper is as follows. In the next section we briefly survey the relevant literature. In section 3 we describe the data. Section 4 develops the econometric approach. In section 5 we report our findings using the IMF exchange-rate-regime classification. In section 6, we use the new Reinhart and Rogoff classification, incorporate domestic price crises into the empirical analysis and report our findings. The paper concludes in section 7 .

\section{Literature}

Recall that it has been a difficult empirical task to identify clear-cut real effects of exchange-rate regimes on the open economy. Indeed, Marianne Baxter and Alan Stockman (1989) and Robert Flood and Andy Rose (1995) find that there are no significant differences in business cycles across exchange rate regimes. ${ }^{4}$

\footnotetext{
${ }^{3}$ Many economists, who, on trade matters, take a complete free-market position, nevertheless are cautious about complete capital account liberalization. Kaushik Basu (2003) puts this issue succinctly: "For one, the capital market (unlike the market for goods) seldom takes the form in which an agent can borrow as much as she wishes at the going interest rate. Moreover, a person demanding capital is, typically, asked by the lender to explain why she needs the money. The greengrocer, on the other hand, does not ask you why you want oranges before he agrees to sell you some."

${ }^{4} \mathrm{An}$ exception is Rose (2000). In the paper, Rose uses evidence from existing currency unions in the world economy, to estimate the effect of currency unions on international trade. Rose finds that a currency union (which is an extreme form of a peg) expands bilateral trade between two average member countries by a huge proportion (200\%, and more). Rose's analysis was challenged by Persson (2001). But he also finds significant, albeit a more modest, effect of currency unions. See also a recent study by Levy-Yeyati and Sturzenneger (2000), who find real effects of exchange-rate regime in cross-country data.
} 
Similarly, no definitive view emerges as to the aggregate effects of capital account liberalizations. Eichengreen (2001) overviews the literature, pointing to the lack of the profession's understanding of the policies. Rodrik (1998) finds no significant statistical association between capital account openness and growth. A more definite view concerning positives effects of capital account liberalization on output, which is advanced by Fischer (1998), is supported by some evidence, provided by Quinn (1997). The role of preexisting policies, and of trade-account-capital-account sequencing, in determining the effects of capital control liberalization on growth and investment, is examined by Arteta, Eichengreen and Wyplosz (2001), Chinn and Ito (2002), and Tornell, Westermann, and Martinez (2004). ${ }^{5}$

The multiple-equilibrium financial crises theory does not provide a clear guide as to the role played by self-fulfilling expectations in financial crises. This is because in the theory the probability of a crisis is loosely related to the fundamentals. ${ }^{6}$ Thus, it leaves as an open question whether observed fundamentals, such as government deficits, are sufficient to explain crisis outcomes; or whether there is a large unexplained component, that is attributed to self-fulfilling expectations. This feature of the theory runs counter to the intuition that bad fundamentals are more likely to trigger a currency crisis. Indeed, the more recent financial-crisis theory demonstrates that, in the presence of asymmetric infor-

\footnotetext{
${ }^{5}$ See also Ariyoshi et al (2000), Bhagwati (1998), Edwards (1999, 2000) and Kaplan and Rodrik (2000). Note that the Chinese Renminbi has been pegged to the US Dollar throughout the the Asian crisis, and also after the crisis. At the same time, China went through a gradual process of removing the constraints on its closed capital account, while maintaining the rigid fixed exchange rate. Its high growth performance, since 1978, is by now well established. East Asia is moving currently towards closer cooperation on trade, bonds markets, currencies, and the management of foreign exchange reserves, which may eventually lead to a common Asian currency.

${ }^{6}$ The 1992 EMS currency crisis inspired the second-generation models, as in Obstfeld (1994). He explained crises as a consequence of a conflict between fixed exchange rate and the central bank desire to pursue more expansionary monetary policy, than what is consistent with the exchange rate and capital market regimes. The resulting pressure, in the foreign exchange market, can lead to multiple self-fulfilling expectations equilibria. The emerging market currency crises of 1997-8 inspired the third generation model of currency crises, generating subtle mechanisms with multiple self-fulfilling expectations equilibria.
} 
mation, even a small amount of uncertainty with respect to the fundamentals, transforms the equilibrium set into a unique fundamentals-driven equilibrium. ${ }^{7}$ For example, Morris and Shin (2000) develop a model where the fundamentals and the crisis-driven outcomes are indeed correlated. Importantly, self fulfilling beliefs can be summarized by a unique probability of crisis, which, in turn, is a function of observed fundamentals. Specifically, when the fundamentals are weak, the probability is large, and vice versa. The asymmetric -equilibrium setup implies that fundamentals-driven market expectations determine ultimately the observed performance of the economy. This justifies our econometric approach, where the probability of balance-of-payments crisis is at the center of the analysis.

\subsection{Data set}

Our original data set consists of 106 low-and middle-income countries (48 African countries, 26 Asian countries, 26 countries from Latin America and the Caribbean, and 5 European countries). A subset of 100 countries, for which we have complete data, is listed in Table 1. The main source of data is the World Bank (World Development Indicators and Global Development Finance). The annual data ranges from 1971 to 1996. The data on 100 countries over the period 1971-1997 is assembled by Gian Maria Milesi-Ferretti and Assaf Razin (2000).

The IMF standard official classification of exchange rate regimes prior to 1997, as described in the various issues of the IMF's Annual Report on Exchange Rate Arrangements and Exchange Rate Restrictions, was completely revamped by the pioneering work of Reinhart and Rogoff (2004).

Capital-account openness data are based on a weighted- average index of several categories restrictions on capital account transactions, reported in the IMF Annual Report on Exchange Arrangements and Exchange Restrictions. ${ }^{8}$ Data on GDP per capita is taken from Summers and Heston Penn Tables 5.6. Real Exchange Rate, Fiscal Balance are

\footnotetext{
${ }^{7}$ See, for example, Goldstein and Pauzner (1999).

${ }^{8}$ These are rule-based, but not quantitative measures. For alternative measures, see also Edison et al (2004).
} 
taken from the World Bank World Tables.

In this paper we take advantage of both the IMF and the Reinhart-Rogoff classifications of exchange-rate regimes. We start with the IMF classification, for which we have the complete sample of countries. We then repeat the analysis, using the Reinhart-Rogoff classification using a sub-sample of 58 countries.

\subsection{Sudden stop crises and policy switches}

Our objective is to explain empirically the effects of balance-of-payments policies on output growth, for economies where balance-of-payments crises are probable. Policy switch and a balance-of-payments crisis state are indicated by a binary variable.

Sudden stop crises are defines by a sharp depreciation in the real exchange rate. In doing so we attempt to capture the effects of the crisis on the real side of the economy. ${ }^{9}$ Specifically, we think of the channel which emphasizes the role of the firm's balance sheet in determining its ability to invest; and the way the firm reacts to large and unexpected real depreciations. Evidently, unexpected fluctuations in the real exchange rate, rather than the fluctuations in the nominal exchange rate, are the ones which are likely to have significant balance-sheet effects. ${ }^{10}$ Concretely, the balance-of-payments crisis is defined by sharp changes of the real exchange rate, with a 15 percent-per-year threshold.

Table 2 describes the frequency of sudden-stop crises, exchange-rate regime, and capital-account policy switches. Overall, about $22 \%$ of the observations are associated

\footnotetext{
${ }^{9}$ Typically in the currency crisis literature sudden stops are measured by free falls in the nominal exchange rate. However, this does not distinguish between domestic price crises and balance-of-payments crises. In our indicator, crisis episodes do not include, therefore, countries which suffer from bouts of high inflation and currency depreciation, but with a relatively stable real exchange rate, because they do not qualify to be classified as balanced-of-payments crises. Evidently, the real exchange rate measure for crisis is strongly correlated with sharp reversals in the current-account balance. See Milesi-Ferretti and Razin (2000). See also Calvo, Izquierdo and Majia (2004) on sudden stops and real exchange rate fluctuations.

${ }^{10}$ See Bacchetta, Aghion and Banerjee (2001), Krugman (2000), Allen, Rosenberg, Keller, Sester, and Roubini (2002), and Eichengreen and Hausmann (1999).
} 
with balance-of-payments crises; an average of $1 \%$ to $4 \%$ of the observations indicate a float-to-peg, peg-to-float, liberalization-to-capital-controls, or capital-controls-to-liberalization policy switches.

\section{The Econometric Framework}

To evaluate the cyclical and the persistent growth effects of the exchange-rate-regime policy switch and a capital-account-openness policy switch, we address two econometric issues. First, the potentially confounding effect on growth of the policy switch, working through the two conflicting channels. Second, the potential endogeneity of policy.

\subsection{The statistical model}

Let $Y_{1, j, t}$ denote the growth rate of country $j$ in time $t$ as measured in terms of GDP per capita. Let $Y_{2, j, t}^{*}$ denote a latent variable indicating the crisis prone state of the economy.

That is, if $Y_{2, j, t}^{*} \geq 0$, a currency crises occurs, whereas if $Y_{2, j, t}^{*}<0$ a currency crises does not occurs. That is:

$$
Y_{2, j, t}=\left\{\begin{array}{ll}
1 & \text { if } Y_{2, j, t}^{*} \geq 0 \\
0 & \text { else }
\end{array},\right.
$$

where, $Y_{2, j, t}$ is a binary variable which equals 1 if currency crises occurs in country $j$ at time $t$ and 0 otherwise.

Consider two policies: (i) a float-peg policy and (ii) a liberalization-controls policy. To simplify, assume that a policy is binary. Denote by $D_{1}$ the float-peg policy and by $D_{2}$ the liberalization-controls policy:

$$
D_{1, j, t}=\left\{\begin{array}{ll}
1 & \text { if peg } \\
0 & \text { if float }
\end{array},\right.
$$

and:

$$
D_{2, j, t}= \begin{cases}1 & \text { if capital controls } \\ 0 & \text { if liberalization }\end{cases}
$$


To simplify let us assume that both $Y_{1, j, t}$ and $Y_{2, j, t}$ can be expressed as a linear function of policy variables $\left(D_{1}, D_{2}\right)$, standard controls $(X)$. The growth equation is as follows.

$$
Y_{1, j, t}=\beta_{1} X_{j, t}+\gamma_{1} D_{1, j, t}+\delta_{1} D_{2, j, t}+\phi_{1} Y_{2, j, t}^{*}+\varepsilon_{1, j, t},
$$

where, $\varepsilon_{1, j, t}$ is a country specific time variant i.i.d. random shock. Similarly the latent variable equation is a linear function of policy variables $\left(D_{1}, D_{2}\right)$ and standard controls $(Z)$ :

$$
Y_{2, j, t}^{*}=\beta_{2} Z_{j, t}+\gamma_{2} D_{1, j, t}+\delta_{2} D_{1, j, t}+\phi_{2} Y_{1, j, t}+\varepsilon_{2, j, t},
$$

where, $\varepsilon_{2, j, t}$ is a country specific time variant i.i.d. random shock.

Let $P_{j, t}$ be the conditional probability that country $j$ will face currency crisis in period $t$, that is $P_{j, t}=\operatorname{Pr}\left(Y_{2, j, t}=1 \mid \cdot\right)$. Given our assumption,

$$
P_{j, t}=\operatorname{Pr}\left(\beta_{2} Z_{j, t}+\gamma_{2} D_{1, j, t}+\delta_{2} D_{1, j, t}+\phi_{2} Y_{1, j, t}>-\varepsilon_{2, j, t}\right)
$$

Assuming that $\varepsilon_{2, j, t} \sim N(0,1)$ then:

$$
P_{j, t}=\Phi\left(\beta_{2} Z_{j, t}+\gamma_{2} D_{1, j, t}+\delta_{2} D_{2, j, t}+\phi_{2} Y_{1, j, t}\right)
$$

where $\Phi$ is the cdf of the unit normal distribution (above).

Note that we can identify the parameters of the "crisis-selection" equation by estimating the Probit equation (7), where the projected likelihood is:

$$
\hat{P}_{j, t}=\Phi\left(\hat{\beta} Z_{j, t}+\hat{\gamma}_{2} D_{1, j, t}+\hat{\delta}_{2} D_{1, j, t}+\hat{\phi}_{2} Y_{1, j, t}\right)
$$

Assuming momentarily that policy is exogenous ${ }^{11}$ we could recover the parameters of interest in the growth equation by estimating the following equation:

$$
Y_{1, j, t}=\beta_{1} X_{j, t}+\gamma_{1} D_{1, j, t}+\delta_{1} D_{2, j, t}+\phi_{1} \Phi^{-1}\left(\hat{Y}_{2, j, t}^{*}\right)+\varepsilon_{1, j, t},
$$

Equation (9) provides consistent estimates for the parameters of interest.

\footnotetext{
${ }^{11}$ Typically, policy action is endogenous. Thus obviously we cannot identify the parameters of interest using the OLS estimators for equations (4) and (7). Therefore, we use lag variables to instrument policy variables $D_{1, j, t}$ and $D_{2, j, t}$.
} 


\subsection{The confounding effect of policies}

To illustrate the importance of incorporating crises state into the empirical analysis assume that the standard growth equation is estimated using valid instrument for policy variables. Consider the confounding of the direct and indirect effects of balance-of-payments policies on growth.

The estimated growth effect of $D_{1}$ and $D_{2}$ when the likelihood of a currency crisis is ignored are:

$$
E\left(\hat{\gamma}_{1}^{I V}\right)=\frac{\partial E\left(Y_{1, j, t} \mid X_{j, t}, D_{1, j, t}^{I V}, D_{1, j, t}^{I V}\right)}{\partial D_{1, j, t}}=\gamma_{1}+\phi_{1} \frac{\partial \Phi^{-1}\left(\hat{Y}_{2, j, t}^{*}\right)}{\partial D_{1, j, t}}
$$

and:

$$
E\left(\hat{\delta}_{1}^{I V}\right)=\frac{\partial E\left(Y_{1, j, t} \mid X_{j, t}, D_{1, j, t}^{I V}, D_{1, j, t}^{I V}\right)}{\partial D_{2, j, t}}=\delta_{1}+\phi_{1} \frac{\partial \Phi^{-1}\left(\hat{Y}_{2, j, t}^{*}\right)}{\partial D_{2, j, t}}
$$

where $D_{1, j, t}^{I V}, D_{1, j, t}^{I V}$ are the instrumented policy variables.

It is common wisdom that the likelihood of currency crisis has a negative effect on growth:

$$
\phi_{1}<0
$$

It is also common to assume that a peg exchange rate increases the likelihood of a currency crisis (all other things equal), and that capital controls reduce the probability of such a crisis:

$$
\begin{aligned}
& \frac{\partial \Phi^{-1}\left(\hat{Y}_{2, j, t}^{*}\right)}{\partial D_{2, j, t}}>0 \\
& \frac{\partial \Phi^{-1}\left(\hat{Y}_{2, j, t}^{*}\right)}{\partial D_{2, j, t}}<0
\end{aligned}
$$

Therefore, the IV estimate for the effect of exchange-rate regime on growth equals to:

$$
E\left(\hat{\gamma}_{1}^{I V}\right)=\gamma_{1}+\phi_{1} \frac{\partial E\left(\Phi^{-1}\right)}{\partial D_{1, j, t}}<\gamma_{1}>0
$$

where the IV estimate for the effect of capital controls on growth is:

$$
E\left(\hat{\delta}_{1}^{I V}\right)=\delta_{1}+\phi_{1} \frac{\partial E\left(\Phi^{-1}\right)}{\partial D_{2, j, t}}>\delta_{1}<0 .
$$


Note that the $\partial E\left(\Phi^{-1}\right) / \partial D_{1, j, t}$ and $\partial E\left(\Phi^{-1}\right) / \partial D_{1, j, t}$ are the the (sample) average effect of the policy on the probability of facing a crisis. As long as the shocks are not

uniformly distributed, $\frac{\partial E\left(\Phi^{-1}\right)}{\partial D_{2, j, t}}>\frac{\partial\left(\Phi^{-1}\right)}{\partial D_{2, j, t}}$ for countries with strong fundamentals, and $\frac{\partial E\left(\Phi^{-1}\right)}{\partial D_{2, j, t}}<\frac{\partial\left(\Phi^{-1}\right)}{\partial D_{2, j, t}}$ for country with weak fundamentals. Moreover, by ignoring the likelihood of a sudden stops crisis, in evaluating the effect of peg-float or liberalization-controls policies on growth, one understates the direct effect of each one of these policies. Namely, the ceteris paribus positive effect of a peg policy on growth is biased downwardly to zero and the ceteris paribus negative effect of capital controls on growth is upwardly biased toward zero.

Why should a policy maker care about the ceteris paribus effect of a policy rather than the reduced form effect?

Our model makes clear that the overall effect of policy $\left(D_{1}\right.$ and $\left.D_{2}\right)$, via the crisisprobability channel, is intrinsically non-linear. There is a range of values of the determinant variables in which the effect of policy on the likelihood of a crisis is large, and another where it is small. Accordingly, the overall effect of the policy on growth depends on the values of determinants of the the crisis probability.

\section{IMF classification: findings}

We estimate both the cyclical as well as the persistent effects of exchange-rate and capitalcontrols regimes on growth, controlling for their effect on the likelihood of a sudden-stop crisis. We report out findings in Table 3 and Table 4.

We start with the effects of float-peg and capital-controls-liberalizations switches. We do so, with, and without country fixed effects. To underscore the role of policy on growth via its indirect effect on the probability of a crisis, we estimate each specification twice, including and excluding the probability of a crisis.

The main findings of Table 3 are: (i) Confounding the direct and indirect effects, if the crisis probability is absent from the growth equation, we find negligible effects of policy switches; (ii) Policy switches do affect the likelihood of a crisis: a switch from float to 
peg increases the probability of a crisis by approximately 30 percent; similarly, capital controls reduce the likelihood of a crisis by the same order of magnitude; (iii) Controlling for the crisis probability in the growth equation, we find a substantial positive effect of the switch from a float to a peg and a substantial negative effect of imposing capital controls, with about the same order of magnitude.

Turning to the effects in the short and the long run, Table 4 demonstrates that: (i) While policy switches do affect the crisis probability, policy levels do not; (ii) Controlling for the crisis probability in the growth equation, the two policy switches, as well as the two policy levels, affect growth; (iii) However, conditioning out the country (time) invariant heterogeneity, policy switches, but not policy levels, affect growth; (iv) Controlling for country fixed effect, we find that the long run effects of policies are insignificant. The latter is due to the fact that it is hard to distinguish between country fixed effects and the permanent effects of exchange rate regime and capital controls on growth. 


\section{The Reinhart-Rogoff classification and the role of domestic price crises}

Calvo and Reinhart (2002) have emphasized that many countries that claim to have floating exchange rates do not allow the exchange rate to float freely, but rather deploy interest rate and intervention policy to affect its behavior. From this point they appear to draw two conclusions: first, that the claim that countries are moving away from adjustable peg exchange rate systems is incorrect; and second, that countries for good reasons hanker after fixed exchange rates, which they can best obtain through hard pegs. This idea prompted an interest in a new classification of exchange rate regimes. Reinhart and Rogoff (2004) attempt to measure the implications of the "fear of floating" problem.

The IMF standard official classification of exchange rate regimes prior to 1997, as described in the various issues of the IMF's Annual Report on Exchange Rate Arrangements and Exchange Rate Restrictions, was thereby completely revamped by Reinhart and Rogoff (2004). They classify the regimes in a range from free falling to a hard peg like in the CFA franc zone in Africa.

In line with Reinhart and Rogoff our findings in the previous section that exchangerate policy switches, rather than policy levels, affect growth, may reflect some missclassifications.

Domestic price crises have been also the subject of growth research. For the empirical literature that looks at the relationships between inflation and growth, Bruno and Easterly (1998) propose a method which is based on discrete high inflation crises. That is, periods when inflation is above some threshold, say 40 percent a year. They find that growth falls sharply during discrete high inflation crises, then recovers quickly after inflation falls below the threshold. Their approach, however, implies that growth is negatively affected by inflation only above the threshold. In other words, inflation affects growth only when a domestic crisis prices in fact occurs. In contrast, our approach points to the role of the fundamentals as reflected in the probability of a crisis on growth, even if the crisis episode is not realized. 
One way to model the effect of the fundamentals underlying a domestic price crisis on growth is by adding the probability of the domestic price crises as an argument in the growth equation (see equation (4)). Another way is to incorporate these fundamentals directly as an argument in the sudden stop probability equation (5).

We preview the estimation of the model with basic statistics about float-peg switches, external and domestic crises. Table 5a describes the frequency of currency and price crises in the sub-sample for which we have the Reinhart-Rogoff classification. Table 5b describes the frequency of exchange-rate regime switches. Comparing the table 5a and 5b to Table 1 , we see that in the new classification of exchange rate regimes the frequency of exchange rate policy switches is significantly larger.

In Table 6 we report our estimates for the growth equation using the Reinhart-Rogoff classification.

We find, like in the IMF classification, that the probability of sudden stops is a major factors in explaining the variation in the persistent growth of countries. Classifying into float and peg using the Reinhst-rogoff classification we find that the policy level, rather than policy switch, affect significantly growth. Now turn to the effect of domestic nominal prices on growth. When domestic price crises are excluded as a determinant of real exchange rate crisis probability, the latter has a significant negative effect on growth. Similarly, when domestic price crises are included as a determinant of a sudden stop crisis probability, the latter has a significant negative effect on growth. But, when both the sudden stop crisis probability, which includes nominal price crises, and the sudden stop crisis probability, which excludes nominal price crisis, appear in the growth equation, only the former has a significant negative effect. This means that a nominal price crisis affects growth only via its affect on sudden stop crises.

\section{Conclusion}

Our model makes clear that the overall effect of balance-of-payments policy is intrinsically non-linear, via the crisis-probability channel. There is a range of the explanatory variables 
in which the effect of policy on the likelihood of a crisis is substantial, whereas there are other ranges where it is not. The expected ceteris paribus effect of a policy switch varies with the magnitude of the crisis-probability. Accordingly, exogenous shocks to the underlying economy affect the desirability of policies such as exchange-rate regime and capital-account liberalization.

Many developing countries, which have switched from float to peg, did so as a means of stabilizing inflation. ${ }^{12}$ Nonetheless they experienced different growth rates. For instance, consider the switched from float to peg in Israel ( 1985) and in Argentina (1991). Israel managed the probability of sudden stops by gradual liberalization and a more flexible exchange-rate policy. In contrast, Argentina hankered around a currency board system and fully liberalized its capital account, both increasing the probability of sudden stops. This may explain the different growth performances of these two countries.

Future research can address also the issue of dollarization. Conventional wisdom suggests that a switch from a float to a peg reinforces dollarization. Currency crises in dollarized economies are expected to be triggered by self-fulfilling expectations, and have adverse output effects through a balance-sheet-crisis mechanism (as in Paul Krugman (2000)). Reinhart, Rogoff and Savastano (2004) find that dollarization appear to increase exchange rate pass-through. This mechanism may reinforce the claim that "fear of floating" is a greater problem for highly dollarized developing economies. ${ }^{13}$

Our approach should not be limited to the study of sudden stops crises, balanceof-payments policies and growth. In fact, this framework is potentially useful for the evaluation of policies, when the fundamentals of a crisis affect the desired outcomes, yet their realizations are not very frequent. For example, monetary and fiscal policies may often affect the fundamentals behind banks and stock market crises. Proper evaluation of these policies should not ignore their effect on the probability of a crisis, although actual crises are not very frequent.

\footnotetext{
${ }^{12}$ For an integrated analysis see Calvo and Vegh (1999).

${ }^{13}$ See also Calvo and Reinhart (2000).
} 


\section{References}

[1] Allen, Mark, Christoph Rosenberg, Christian Keller, Brad Sester, and Nouriel Roubini, "A Balance Sheet Approach to Financial Crisis," IMF WP/02/210, International Monetary Fund.

[2] Ariyoshi, Akira, Karl Habermeier, Bernard Laurens, Incintker-Robe, Jorge Ivan Canales-Kriljenko, and Andrei Kirilenko (2000). Capital Controls: Country Experiences with Their Use and Liberalization, IMF Occasional Paper 190.

[3] Arteta, Carlos, Barry Eichengreen, and Charles Wyplosz, (2001). "When Does Capital Account Liberalization Help More Than It Hurts?" NBER Working Paper No. 8414.

[4] Bacchetta, Philippe, Philippe Aghion, and A. Banerjee (2001) "Currency Crises and Mone, in Credit-Constrained Economies," European Economic Review, 45, 11211150.

[5] Basu, Kaushik (2003) "Globalization and the Politics of International Finance: The Stiglitz Verdict," Journal of Economic Literature, Vol. XLI (September) pp 885-899.

[6] Baxter, Marianne, and Alan Stockman (1989) "Business Cycle and Exchange Regime: Some International Evidence," Journal of Monetary Economics Vol. 23, 377-400)

[7] Bhagwati, Jagdish (1998). "The Capital Myth", Foreign Affairs, 77, 3 (May-June), $7-12$.

[8] Bruno, Michael, and William Easterly, (1998). "Inflation Crises and Long-run Growth," Journal of Monetary Economics, 41, (February), 3-26.

[9] Calvo, Guillermo A. (2000). "Capital Markets and the Exchange Rate, With Special Reference to the Dollarization Debate in Latin America", University of Maryland, (April). 
[10] - Alejandro Izquierdo, and Luis-Fernando Mejia (2004). On the Empirics of Sudden Stops: The Relevance of Balance-Sheet Effects, mimeo, University of Maryland, May.

[11] — and Carmen M. Reinhart (2000). "Reflections on Dollarization", in Alberto Alesina and Robert Barro (editors), Currency Unions, forthcoming. Stanford: Hoover Institution Press.

[12] — and Carmen M. Reinhart (2002). "Fear of Floating", The Quarterly Journal of Economics, Volume CXVII, No. 2, May, 379-408.

[13] - Carmen M. Reinhart, and Carlos A. Vegh (1995). "Targeting the Real Exchange Rate: Theory and Evidence", Journal of Development Economics, 47, 97-133.

[14] — and Carlos Vegh (1999). "Inflation Stabilization and BOP Crises in Developing Countries", NBER Working Paper 6925.

[15] Chang, Roberto and Andres Velasco (2000). "Exchange Rate Policy for Developing Countries", American Economic Review, Papers and Proceedings, 90, 2 (May), 71-75.

[16] Chinn, Menzie D. and Hiro Ito (2002). "Capital Account Liberalization, Institutions and Financial Development: Cross Country EVidence," NBER Working Paper No. 8967.

[17] Edison, Hali, Michael Klein, Luca A. Ricci, and Torsten M. Slok (2004). "Capital Account Liberalization and Economic Performance: Survey and Synthesis," IMF Staff Papers, Vol 51.

[18] Edwards, Sebastian (1999). "How Effective are Capital Controls?", Journal of Economic Perspectives, 13, 4 (Fall), 65-84.

[19] (2000). "Exchange Rate Regimes, Capital Flows and Crisis Prevention", NBER (December). 
[20] Eichengreen, Barry, (2001). "CapitalAccount Liberalization: What Cross-Country Studies Tel Us?" World Bank Economic Review,15: 341-365.

[21] Eichengreen, Barry, and Ricardo Hausmann (1999). "Exchange Rates and Financial Fragility", NBER Working Paper 7418 (November).

[22] Fischer, Stanley (1998). "Capital-Account Liberalization and the Role of the IMF", in Should the IMF Pursue Capital-Account Convertibility? Princeton Essays in International Finance,20\%: 1-10. Princeton University, International Finance Section,

[23] Fischer, Stanley (2001). "Distinguished Lecture on Economics in GovernmentExchange Rate Regimes: Is the Bipolar View Correct? The Journal of Economic Perspectives, Volume 15, Number 2, Spring 2001, 3-24.

[24] Fischer, Stanley, and David W. H. Orsmond (2002). "Israeli Inflationfrom an International Perspective," in Avi Ben-Bassat (Editor), The Israeli Economy, 1985-1998, The MIT Press, pp.157-186.

[25] Flood, Robert P. , and Andy Rose (1995),"Fixing Exchange Rates: A Virtual Quest for Fundamentals," Journal of Monetary Economics.

[26] Ghosh, Atish R., Anne-Marie Gulde, and Holger C. Wolf (2000). "Currency Boards: More than a Quick Fix?", Economic Policy, 31 (October), 270-335.

[27] Goldstein, Itay and Ady Pauzner (1999), "Endogenous Probability of Bank Runsin a Rational Expectations Model," Tel Aviv University.

[28] IMF, Annual Report on Exchange Arrangements and Exchange Restrictions, various years.

[29] Kaplan, Ethan and Dani Rodrik (2000). "Did the Malaysian Capital Controls Work?", Kennedy School of Government (December).

[30] Krugman, Paul (2000), "Balance Sheets, The Transfer Problem, and Financial Crises," in International Finance and Financial Crises: Essays in Honor of Robert 
P. Flood, Jr. Edited by Peter Isard, Assaf Razin, and Andrew K. Rose, Kluwer Academic Publishers, pp. 31-44.

[31] Levy-Yeyati, Eduardo and Federico Sturzenegger (2000). "Exchange Rate Regimes and Economic Performance", paper presented at IMF First Annual Research Conference (November).

[32] Milesi-Ferretti, Gian Maria, and Assaf Razin (2000), in Paul Krugman (ed.), Currency Crises, University of Chicago Press.

[33] Morris, Stephen, and Hyun Song Shin (2000), "Rethinking Multiple Equilibria in Macroeconomic Modelling," NBER Macroeconomics Annual, Number 15, 139-161.

[34] Morris Stephen and Hyun Song Shin (2000), Rethinking Multiple Equilibria in Macro Modeling," NBER Macroeconomic Annual, 2000, pp. 139-161.

[35] Milesi-Ferretti, Gian Maria, and Assaf Razin (2000). "Current Account Reversals and Currency Crises: Empirical Regularities," in Paul Krugman (Editor), Currency Crises, University of Chicago Press, 285-323.

[36] Obstfeld, Maurice (1994), "The logic of Currency Crises," Cahiers Economique et Monetairs, 43, 189-212.

[37] Obstfeld, Maurice and Kenneth Rogoff (1995). "The Mirage of Fixed Exchange Rates", Journal of Economic Perspectives, 9, 4 (Fall), 73-96.

[38] Quinn, Dennis, (1997), "The Correlates of Change in International Financial Regulation," American Political Science Review, Vol. 91, No. 3, (September), pp.531-51.

[39] Persson, Torsten, (2001) " "Currency unions and trade: How large is the treatment effect?" Economic Policy 33, 433-448.

[40] Reinhart, Carmen, and Ken Rogoff (2004), "The Modern History of Exchange Rate Arrangements: A Reinterpretation," Quarterly Journal of Economics, Vol. 119, Issue 1, February, pp. 1 - 48. 
[41] Reinhart, Carmen, Ken Rogoff and Miguel Savastano (2004), NBER Working Paper \# 10015, forthcoming in the Quarterly Journal of Economics.

[42] Rodrik, Dani, (1998), "Who needs Capital-Account Convertibility?" Princeton Essays in International Finance,20\%: 55-65.

[43] Rose, Andrew, (2000). "One Money, One Market: Estimating the Effect of Common Currencies on Trade," Economic Policy, Issue 30, pp. 7-45.

[44] Tornell, Aaron, Frank Westermann and Lorenza Martinez, (2004). "The Positive Link Between Financial Liberalization, Growth, and Crises," NBER Working Paper No. 10293, February.

[45] Williamson, John (2000). Exchange Rate Regimes for Emerging Markets: Reviving the Intermediate Option. Washington, DC: Institute for International Economics (September). 
Table 1:

The Frequency of Crises, Switches Between Float and Peg and Switches between Capital Controls and Liberalizations (\%)

Variable

Frequency

Crsises

22.61

Switches to peg

1.71

Switches to float

3.91

Switches to controls

1.03

Switches to liberalizations

0.9 
Table 2:

List of Countries
(1) Algeria
(51)
Malawi
(2) Argentina
(52)
(3) Bangladesh
(53)
(4) Barbados
(54)
(5) Belize
(55)
(6) Benin
(56)
(7) Bhutan
(57)
(8) Bolivia
(58)
(9) Botswana
(59)
(10) Brazil
(60)
(11) Burkina Faso
(61)
(12) Burundi
(62)
(13) Cameroon
(63)
(14) Cape Verde
(64)
(15) Central African
(65)
(16) Chad
(66)
(17) Chile
(67)
(18) China
(68)
(19) Colombia
(69)
(20) Comoros
(70)
(21) Congo
(71)
(22) Cote d'Ivoire
(72)
(23) Dominican Rep.
(73)
(24) Ecuador
(74)
(25) Egypt, Arab Rep
(75)
(26) El Salvador
(76)
(27) Equatorial Guin
(77)
(28) Ethiopia
(78)
(29) Fiji
(79)
(30) Gabon
(80)
(31) Gambia, The
(81)
(32) Ghana
(33) Grenada
(34) Guatemala
(84)
(35) Guinea
(36) Guinea-Bissau
(86)
(37) Guyana
(87)
(38) Haiti
(88)
(39) Honduras
(89)
(40) Hungary
(90)
(41) India
(42) Indonesia
(92)
(43) Iran, Islamic R
(93)
(44) Jamaica
(94)
(45) Jordan
(95)
(46) Kenya
(96)
(47) Lao PDR
(97)
(48) Lesotho
(98)
(49) Liberia
(50) Madagascar
(99) 
Table 3:

Exchange Regime and Capital Controls: Cyclical Effects

\section{Panel A: Dependent Variable: Growth Rates}

Variables

Switching to peg between t-2 to t-1

Switching to float between $\mathrm{t}-2$ to $\mathrm{t}-1$

Switching to Capital Controls between $\mathrm{t}-2$ to $\mathrm{t}-1$

The probability of having currency crisis this year ^

\section{Controllers}

1970 GDP per capita

Currency crisis at time t-1

Currency crisis at time t-2

Growth rate at time t-1

Growth rate at time t-2

\begin{tabular}{|c|c|c|c|}
\hline $\begin{array}{l}\text { OLS } \\
\text { (i) }\end{array}$ & $\begin{array}{l}\text { OLS } \\
\text { (ii) }\end{array}$ & $\begin{array}{l}\text { FE } \\
\text { (iii) }\end{array}$ & $\begin{array}{ll}\text { FE } & \\
& \text { (iv) } \\
\end{array}$ \\
\hline $\begin{array}{l}1.6423 \\
(0.7503)^{\star}\end{array}$ & $\begin{array}{l}4.6209 \\
(1.4795)^{\star *}\end{array}$ & $\begin{array}{l}1.2041 \\
(0.9958)\end{array}$ & $\begin{array}{l}5.0215 \\
(1.7630)^{\star *}\end{array}$ \\
\hline $\begin{array}{l}0.1761 \\
(0.6483)\end{array}$ & $\begin{array}{l}0.6383 \\
(0.6692)\end{array}$ & $\begin{array}{l}-0.0539 \\
(0.7039)\end{array}$ & $\begin{array}{l}0.2005 \\
(0.7401)\end{array}$ \\
\hline \multirow[t]{2}{*}{$\begin{array}{l}-1.8832 \\
(0.8616)^{\star}\end{array}$} & $\begin{array}{l}-4.7173 \\
(1.5363)^{\star *}\end{array}$ & $\begin{array}{l}-1.9592 \\
(1.0495)\end{array}$ & $\begin{array}{l}-6.3843 \\
(2.0713)^{\star *}\end{array}$ \\
\hline & $\begin{array}{l}-9.6164 \\
(5.0663)\end{array}$ & & $\begin{array}{l}-12.7791 \\
(4.9934)^{\star}\end{array}$ \\
\hline
\end{tabular}

$\begin{array}{ll}-0.0012 & -0.0011 \\ (0.0005)^{\star} & (0.0005)^{\star}\end{array}$

0.5612

(0.5949)

2.7602

$(1.2740)^{*}$

0.7579

(0.4506)

2.5482

-2.1345
$(0.6375)^{\star \star}$

$-1.5347$

$(0.7221)^{*}$

$-1.6442$

$(0.4525)^{\star *}$

$-2.2155$

$(0.4852)^{\text {** }}$

0.2540
$(0.0464)^{* *}$

0.2552

$(0.0469)^{\text {** }}$

0.1802

0.2267

$(0.0275)^{\star *}$

$(0.0312)^{\text {** }}$

$\begin{array}{llll}0.1093 & 0.1048 & 0.0069 & -0.0224 \\ (0.0366)^{\star \star} & (0.0372)^{\star \star} & (0.0274) & (0.0313)\end{array}$

Panel B: Dependent Variable: Currency Crisis $(0,1) .1$ if $R E E(t)-R E E(t-1)>15 \%$ - Probit (dF/dX) estimators

1970's GDP per capita

Switching to peg between $\mathrm{t}-2$ to $\mathrm{t}-1$

Switching to float $t-2$ to $t-1$

Switching to Capital Controls between t-2 to t-1

Currency crisis at time t-1

Currency crisis at time t-2

Government def $\mathrm{t}-1^{\wedge \wedge}$

Country fixed-effects
0.0000

(0.0000)

0.3125

0.2893

$(0.0991)^{\star *}$

$(0.1028)^{\star \star}$

0.0557

(0.0510)

0.0325

(0.0516)

$-0.2656$

$-0.3313$

$(0.0470)^{\star *}$

$(0.0524)^{\star \star}$

0.2299

0.1314

$(0.0377)^{\text {** }}$

$(0.0349)^{\star *}$

0.0563

(0.0296)

$-0.0307$

(0.0256)

0.0000

0.0000

$(0.0000)$

(0.0000)

\section{Note:}

Data includes 106 countries in the years 1970 to 1997

${ }^{\wedge}$ Currency crisis $=1$ if the real exchange rate increased by $15 \%$ between $\mathrm{t}-1$ to $\mathrm{t}$ ( 1 STD)

All specifications include linear time trend

( ) Standard errors in parenthesis

* significant at $5 \%$; ** significant at $1 \%$

No

Yes 
Table 4:

Exchange Regime and Capital Controls: Cyclical and Persistent Effects

\section{Panel A: Dependent Variable: Growth Rates}

Variables

Peg at time $\mathrm{t}-1$

Switching to peg between t-2 to t-1

Switching to float between $\mathrm{t}-2$ to $\mathrm{t}-1$

Capital Controls at t-1

Switching to Capital Controls between t-2 to t-1

The probability of having currency crisis this year ${ }^{\wedge}$

\section{Controllers}

1970 GDP per capita

Currency crisis at time t-1

Currency crisis at time t-2

Growth rate at time t-1

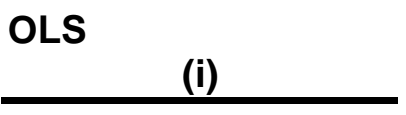

FE

$-0.6088$

$(0.2899)^{*}$

0.1813

(0.4787)
3.9786
4.9046
$(1.2935)^{\star \star}$
$(1.4604)^{\star *}$
0.4657
(0.7124)
0.8090
(0.8382)

$-1.2843$

$-1.1997$

$(0.4539)^{* *}$

(0.9385)

$-1.2843$

$-5.9101$

$(0.4539)^{\star *}$

$(1.7511)^{\star *}$

$-7.9131$

$-13.7764$

(6.0140)

$(4.4409)^{\text {** }}$
$-0.0013$

$(0.0006)^{*}$

2.3069

(1.4183)

2.6221

$(0.7543)^{\star \star}$

$-1.7389$

$(0.7269)^{\star}$

$-2.3438$

$(0.4911)^{\star *}$

0.2481

$(0.0456)^{\star *}$
0.2247

$(0.0312)^{* *}$

\section{Panel B: Dependent Variable: Currency Crisis $(0,1) .1$ if $R E E(t)-R E E(t-1)>15 \%$ - Probit (dF/dX) estimato}

1970's GDP per capita

Peg at time t-1

Switching to peg between t-2 to t-1

Switching to float $t-2$ to $t-1$

Capital Controls at $\mathrm{t}-1$

Switching to Capital Controls between $\mathrm{t}-2$ to $\mathrm{t}-1$

Currency crisis at time $\mathrm{t}-1$

Country fixed-effects

$$
\begin{gathered}
0.0000 \\
(0.0000)
\end{gathered}
$$

$-0.0192$

(0.0221)

0.0368

(0.0361)

0.2798

$(0.1029)^{\star *}$

0.2106

$(0.1070)^{*}$

0.0801

(0.0567)

0.1085

(0.0674)

$-0.0383$

(0.0283)

$-0.1021$

(0.0639)

$-0.2491$

$(0.0513)^{* *}$

$-0.2820$

$(0.0646)^{\star *}$

0.2264

$(0.0373)^{\star *}$

0.1255

$(0.0345)^{\star *}$

No

Yes

\section{Note:}

Data includes 106 countries in the years 1970 to 1997

${ }^{\wedge}$ Currency crisis $=1$ if the real exchange rate increased by $15 \%$ between $\mathrm{t}-1$ to $\mathrm{t}$ ( 1 STD)

All specifications include linear time trend

() Standard errors in parenthesis

* significant at $5 \%$; ${ }^{* *}$ significant at $1 \%$ 
Table 5.a:

The Frequency of Sudden Stop and Domestic Prices Crises

Using Reinhart-Rogoff (2004) Classification*, **

\begin{tabular}{|c|c|c|c|c|}
\hline \multirow{5}{*}{$\begin{array}{l}\text { Sudden Stops } \\
\text { Crises }\end{array}$} & & \multicolumn{3}{|c|}{ Domestic Price Crises } \\
\hline & & 0 & 1 & \\
\hline & 0 & 24.6 & 9.9 & 34.5 \\
\hline & 1 & 29.3 & 36.3 & 65.5 \\
\hline & & 53.9 & 46.1 & 100.0 \\
\hline
\end{tabular}

Notes:

${ }^{*}$ Reinhart and Rogoff (2002) classified into 5 categories: (i) peg,

(ii) limited flexibility, (iii) managed floating, (iv) freely floating and (v) freely falling.

We aggregate it into 2 main categories: (i) peg_rr, including the first 3 and (ii)

float_rr, including the other two.

** Data includes 58 countries in the years 1970 to 1997

Domestic prices crisis $=1$ if the inflation rate is above $20 \%$ per year and 0 otherwise.

Sudden stop crisis $=1$ if the real exchange rate depreciation is above $15 \%$ per year and 0 otherwise. 
Table 5.b:

Switches Between Float and Peg

Using Reinhart-Rogoff (2004) Classification,,**

Variable

Frequency

Switches to peg

10.18

Switches to float

9.97

\section{Notes:}

* Reinhart and Rogoff (2002) classified into 5 categories: (i) peg,

(ii) limited flexibility, (iii) managed floating, (iv) freely floating and (v) freely falling.

We aggregate it into 2 main categories: (i) peg_rr, including the first 3 and (ii)

float_rr, including the other two.

** Data includes 58 countries in the years 1970 to 1997 
Table 6:

Exchange Regime and Capital Controls

Using Reinhart-Rogoff (2004) Classification*, ,*

Fixed-Effects Estimators

\section{Dependent Variable: Growth Rates}

Variables

Peg at time $\mathrm{t}-1$

Capital Controls at $\mathrm{t}-1$

Switching to Capital Controls between t-2 to t-1

The probability of having currency crisis this year ${ }^{\wedge}$ excluding the effect of price crisis

The probability of having currency crisis this year - real^^ including the effect of price crisis (i)

1.656

$(0.557)$

$-0.439$

$(0.890)$

$-5.852$

(1.799)

$-14.843$

(4.937) (ii)

1.330

$(0.549)$

$-0.587$

(0.991)

$-3.374$

$(1.518)$

(iii)

1.729

(0.565)

0.156

(1.022)

$-6.155$

$-22.359$

$-6.824$

7.632

(4.084)

\section{Controllers}

Growth rate at time t-1

$\begin{array}{ccc}0.176 & 0.191 & 0.183 \\ (0.034) & (0.034) & (0.034)\end{array}$

Growth rate at time t-2

$\begin{array}{ccc}0.008 & 0.022 & 0.019 \\ (0.035) & (0.035) & (0.035)\end{array}$

Currency crisis at time t- 1

$\begin{array}{ll}2.812 & 0.917 \\ (0.978) & (0.629)\end{array}$

Currency crisis at time t-2

Price (CPI) crisis at time $\mathrm{t}-1$

$-0.100$

1.078

(0.491)

$(0.772)$

Price $(\mathrm{CPI})$ crisis at time $\mathrm{t}-2$

\section{Notes:}

${ }^{*}$ Reinhart and Rogoff (2002) classified into 5 categories: (i) peg, (ii) limited flexibility, (iii) managed floating , (iv) freely floating and (v) freely falling. We aggregate it into 2 main categories: (i) peg_rr, including the first 3 and (ii) float_rr, including the other two.

** Data includes 58 countries in the years 1970 to 1997

$\wedge$ The estimated the likelihood for a currency crisis ignoring the effect of price crisis.

$\wedge^{\wedge}$ The estimated probability for a currency crisis including the effect of past price crisis

All specifications include linear time trend

( ) Standard errors in parenthesis 